\title{
Synthesis and Biological Evaluation of Sulfur-Containing Cinnamate and Salicylate Derivatives
}

\author{
Chih-Chia Chiang, ${ }^{a}$ Tsu-Chung Chang, ${ }^{*}, b$ Hou-Jen Tsai, ${ }^{a}$ and Ling-Yih Hsu ${ }^{*, c}$ \\ ${ }^{a}$ Department of Applied Chemistry and Materials Science, Institute of Technology, National Defense University; Ta-shi, \\ Tao-yuan 335, Taiwan, ROC: ${ }^{b}$ Department of Biochemistry, National Defense Medical Center; Neihu 114, Taiwan, ROC: \\ and ${ }^{c}$ Department of Biological Science and Technology, China Institute of Technology; Nangang, Taipei 115, Taipei, \\ Taiwan, ROC. Received August 12, 2007; accepted December 18, 2007; published online December 20, 2007
}

UV irradiation induced formation of reactive oxygen radical species and matrix metalloproteinases (MMPs) are thought to be involved in photo-damage to the skin. MMP-1 is the major collagenolytic enzyme responsible for collagen destruction in skin tissue. To develop new anti-photoaging agents, a series of $2,2^{\prime}$-dithiocinnamate derivatives and $2,2^{\prime}$-dithio or 2 -thiobenzoate derivatives were designed and synthesized. The biological activities of the synthesized compounds were assayed for ABTS [2,2'-azinobis-(3-ethyl-benzo-thiazoline-6-sulfonic acid)] radical scavenging activity, MMP-1 inhibitory activity, and cytotoxicity to human dermal fibroblast cells. Compounds with potential of resistance to UV irradiation were identified. These compounds are expected to be useful for preventing photo-damage to the skin.

Key words free radical scavenger; matrix metalloproteinase inhibitor; UV protectant

Human skin is the most susceptible organ to be damaged by ultraviolet (UV) irradiation as it is directly exposed to UV light. Increased evidence has shown the generation of reactive oxygen species (ROS) in the skin upon UV exposure. ${ }^{1-3)}$ Increased ROS generation can overwhelm the intracellular antioxidant-defense mechanism, resulting in oxidative stress and oxidative photo-damage to proteins and other macromolecules in the skin. Oxidative stress is thought to play a central role in initiating and driving the signaling events that lead to the cell response following exposure to UV irradiation. ${ }^{4,5)}$ Exposure of human skin to UV radiation causes numerous biological effects in the skin, including premature aging characterized by wrinkles, leathery texture and mottled pigmentation. ${ }^{67)}$ The mechanism of skin wrinkles is primarily due to the loss of macromolecules making up the dermal matrix, among which collagen is the major component. The degradation of collagens is normally tightly controlled by the activity of a family of zinc-dependent matrix metalloproteinases (MMPs) and their natural inhibitors, the tissue inhibitors of MMPs (TIMPs) ${ }^{8)}$ Although several MMPs are expressed in mammalian skin, studies by Brennan et al. ${ }^{3)}$ showed that the neutralization of MMP-1 removed virtually all the collagen-degrading activity elaborated by UV-treated human skin.

Cinnamates and salicylates are the chemical UV filter widely used throughout the world. ${ }^{9)}$ In this study, the ethyl and 2-ethylhexyl esters of these compounds were synthesized, as the presence of these groups may diminish the water solubility of these compounds to various degree, thus, may help to develop waterproof sunscreen formulation. ${ }^{9}{ }^{9}$ Because the radical scavenging ability of mercaptans and disulfides is well-documented, we speculated that the introduction of these important functional groups into cinnamates or salicylates might yield potent antioxidants and UV protectants. In addition, we reasoned that the disulfides ${ }^{10,11)}$ and $\alpha$-mercaptocarbonyl group ${ }^{12)}$ would chelate zinc ion at the active-site of MMP-1, which renders them to be potential MMP inhibitors. In this work, the sulfur-containing cinnamates and salicylates of substituted ester group were synthesized and the potency of these compounds as UV protective agents was evaluated by analyzing their free radical scavenging and for MMP-1 inhibitory activities.

Chemistry The synthetic routes ${ }^{13-15)}$ to the target compounds 5a, 5b, 6a, 6b and 7a, 7b are outlined in Charts 1 and 2. Reduction of 2-mercaptobenzoic acid with lithium aluminum hydride $\left(\mathrm{LiAlH}_{4}\right)$ in tetrahydrofuran resulted 2mercaptobenzyl alcohol (1), followed by oxidation of $\mathbf{1}$ with pyridinium chlorochromate (PCC) in dichloromethane at room temperature afforded 2,2'-dithiodibenzadehyde (2). Triphenyl-phosphanylidene-acetic acid 2-ethyl-hexyl ester (4) was prepared from triphenylphosphine and bromo-acetic 2-ethyl-hexyl ester, which obtained from the reaction of bromoacetic acid with 2-ethyl-hexanol under toluenesulfonic acid in toluene at reflux temperature. Thus, converting the
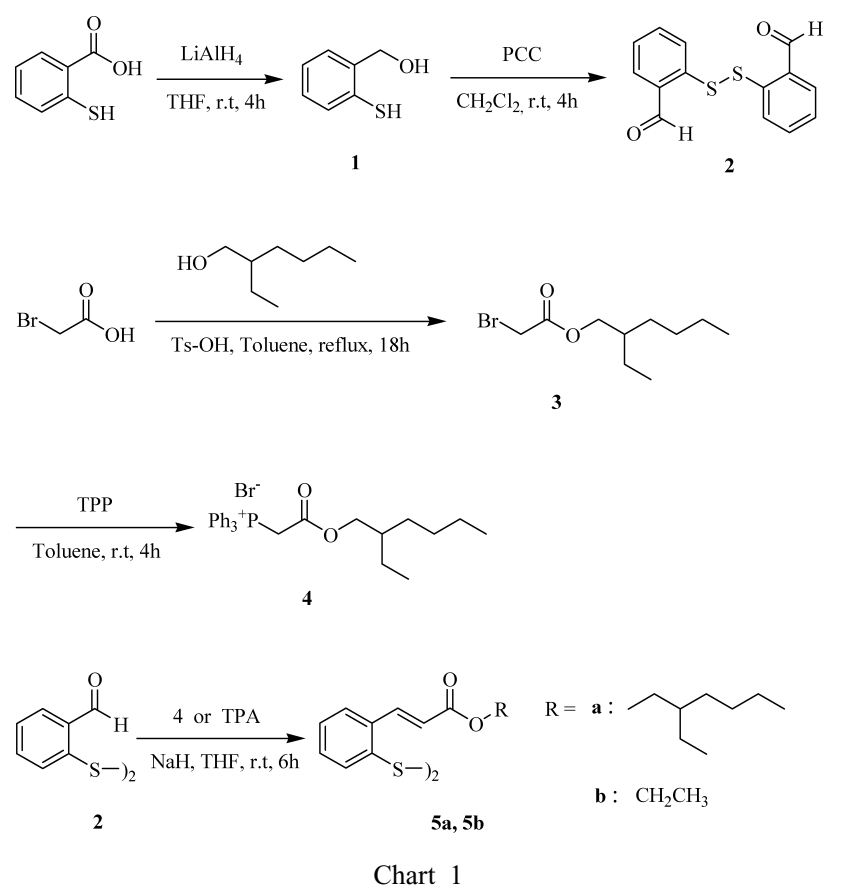


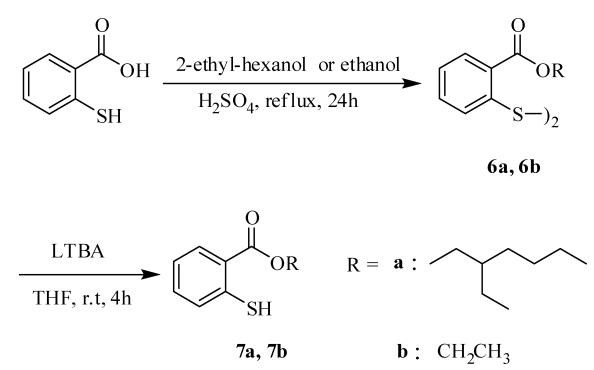

Chart 2

disulfide $\mathbf{2}$ into the desired products $\mathbf{5} \mathbf{a}$ and $\mathbf{5 b}$ by a Wittig reaction of $\mathbf{2}$ with $\mathbf{4}$ and triethylphosphonoacetate (TPA) in tetrahydrofuran (THF) at room temperature, respectively. Target compounds $\mathbf{6 a}$ and $\mathbf{6 b}$ were synthesized by acid-catalyzed Fischer esterification of 2-mercaptobenzoic acid with 2-ethyl-hexanol or ethanol, respectively. Finally, the disulfides $6 \mathbf{a}$ and $6 \mathbf{b}$ were converted into thiols products $7 \mathbf{a}$ and 7b using a reduction with lithium tri-tert-butoxyaluminohydride (LTBA) in THF at room temperature.

\section{Results and Discussion}

Cytotoxicity of Synthetic Compounds The cytotoxicity of compounds $\mathbf{5 a}-\mathbf{7 b}$ was determined by Cell-CountingKit-8 (CCK-8)-assay on human derma fibroblast (HDF) cells. ${ }^{16)}$ The result presented in Fig. 1 showed the cell viability upon treatment with increasing concentrations of test compounds after $48 \mathrm{~h}$. With less than $50 \mu \mathrm{M}$, these compounds displayed no apparent cytotoxicity as compared with the control cells that was treated with $0.01 \%$ DMSO. Increased cytotoxicity was observed in cells treated with $100 \mu \mathrm{m}$ of these compounds.

ABTS Radical Scavenging Assay Scavenging of ABTS [2,2'-azinobis-(3-ethyl-benzo-thiazoline-6-sulfonic acid)] free radical is a convenient method ${ }^{17,18)}$ to evaluate the in vitro antioxidative activity of antioxidants. In addition to compounds $\mathbf{5 a}-\mathbf{7 b}$, trolox and WR2721 were also included as positive and negative control compounds, respectively, for this assay (Fig. 2). Trolox, a potent antioxidant, is frequently used as a positive control in assessing radical scavenging activity. ${ }^{19)}$ WR2721 is an inactive prodrug that is activated to the active thiol metabolite in the cells and that is responsible for its free radical scavenging activity. ${ }^{20)}$ As shown in Table 1 , these compounds displayed various degrees of free radical scavenging activity, with decreasing activity in the following order: Trolox $>\mathbf{7 b}>\mathbf{5 b}>\mathbf{6} \mathbf{a} \approx \mathbf{6} b \geqslant \mathbf{7} a=\mathbf{5 a}>$ WR 2721. Among the tested compounds, compound $\mathbf{7 b}$ showed significant free radical scavenging activity. The effect may be attributed to the free sulfhydryl group in the compound. As the ABTS free radical scavenging assay was carried out in aqueous system. The weak activity of compound $\mathbf{6 a}$ may be due to the decreased water solubility of the ethylhexyl group despite the presence of a free thiol group. For compound $\mathbf{5 b}$, the conjugated double bond system in cinnamate moiety and greater water solubility of ethyl ester group may enhance its scavenging activity. Our results also suggested that the disulfide linkage may reduce the free radical scavenging activity.

Collagen Degradation Assay In the collagen degradation assay, ${ }^{3,7)}$ MMP-1 enzyme and rat tail collagen were incubated with synthetic compounds. The inhibitory potency of

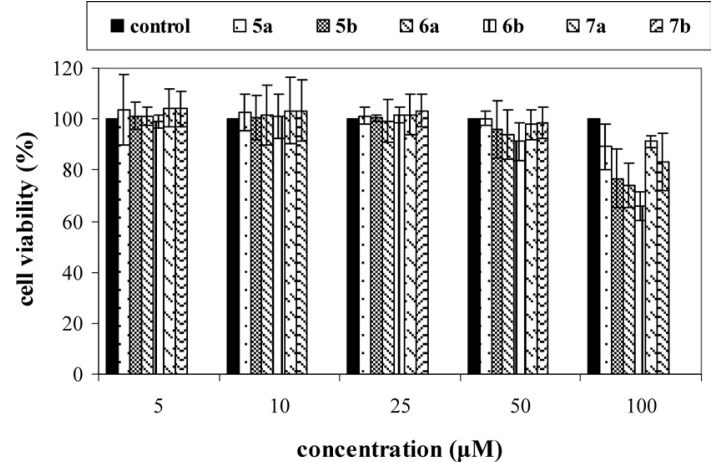

Fig. 1. Viability of HDF Cells Treated with Different Concentrations of $5 a-7 b$

Data were expressed as relative viability and represent mean \pm S.D. $(n=6)$.

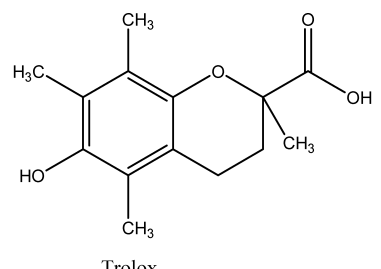

(6-Hydroxy-2,5,7,8-tetramethylchromane-2-carboxylic acid)<smiles>NCCCNCCSP(O)O</smiles>

WR2721 (amifostine)

2-[3-aminopropyl]aminoethyl phosphorothiolate

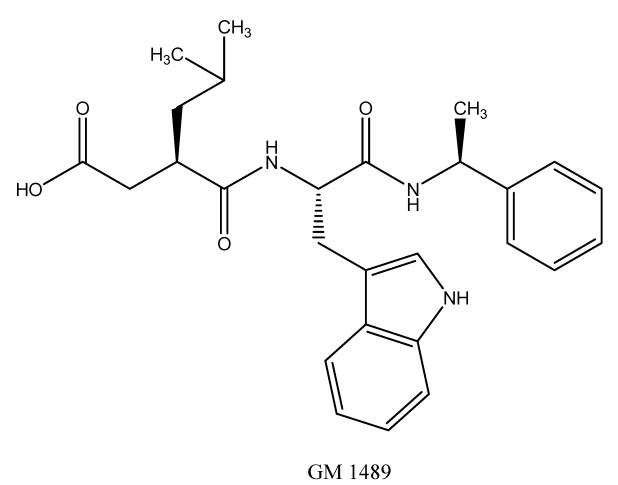

N-[(2R)-2-(carboxymethyl)-4-methylpentanoy]-L-trytoptophan-(s)-methylbenzylamide

Fig. 2. The Chemical Structures of the Control Compounds Trolox, WR2721, and GM-1489

these compounds on MMP-1 activity was assessed by resolving the digested collagen with agarose gel electrophoresis. As shown in Fig. 3, in the absence of MMP-1, the original form of collagen sample has four major bands (lane 1). In the presence of MMP-1 but with no inhibitory compound (lane 2, DMSO), the major collagen bands were digested into smaller fragments after $18 \mathrm{~h}$ of incubation. The starting material for our synthetic compounds, thiosalicylic aicd, was used as a negative control for this assay and which showed no apparent MMP-1-inhibitory activity (lane 3, S). The known 
Table 1. ABTS Radical Cation Scavenging Activity of Compounds 5a$7 \mathbf{b}$

\begin{tabular}{cc}
\hline \hline Compound $(100 \mu \mathrm{M})$ & Scavenging activity $(\%)$ \\
\hline Trolox & $15.3 \pm 1.3$ \\
WR2721 & $0.1 \pm 0.1$ \\
$\mathbf{5 a}$ & $1.8 \pm 0.9$ \\
$\mathbf{5 b}$ & $3.4 \pm 0.7$ \\
$\mathbf{6 a}$ & $2.8 \pm 1.0$ \\
$\mathbf{6 b}$ & $2.5 \pm 0.4$ \\
$\mathbf{7 a}$ & $1.8 \pm 0.3$ \\
$\mathbf{7 b}$ & $6.7 \pm 0.7$
\end{tabular}

Results represent mean \pm S.D. $(n=3)$.

A.

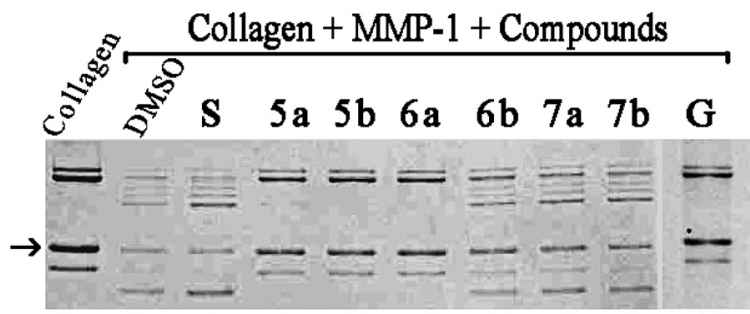

Lane: $\begin{array}{llllllllll}1 & 2 & 3 & 4 & 5 & 6 & 7 & 8 & 9 & 10\end{array}$

B.

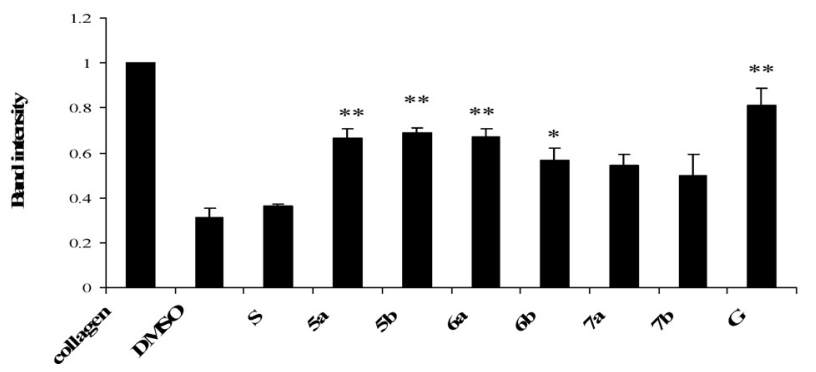

Fig. 3. Inhibition of MMP-1-Mediated Collagen Degradation by Compounds $5 \mathbf{a}-7 \mathbf{b}$

(A) Collagen degradation. Type I collagen was cleaved by purified MMP-1 in the presence of various compounds. S: Thiosalicylic acid (starting material); G: GM-1489 (broad-spectrum inhibitor of MMPs, Fig. 2). (B) Relative inhibitory potency of test compounds on MMP-1 activity. The results are expressed as relative intensity of the third band from top of the gel (arrow indicated). Each bar is the mean \pm S.D. of three independent experiments. $* p<0.05 ; * * p<0.01$ compared with control (lane 1 ) group.

MMP-1 inhibitor, GM-1489, was used as a positive control for protection of collagen from further degradation (lane 10, $\mathrm{G})$. To evaluate the potency of these compounds as MMP-1 inhibitors, the relative intensity of the third major band from the top of the gel was quantitated (arrow marked). The MMP-1 inhibitory activity of these compounds occurred in the following order: GM-1489 $>\mathbf{5 b} \approx \mathbf{6} \mathbf{a} \approx \mathbf{5} \mathbf{a}>\mathbf{6 b}>\mathbf{7 b} \approx \mathbf{7 a}$. Results from this assay indicate that compounds $\mathbf{5 a}, \mathbf{5} \mathbf{b}$, and 6a displayed greater MMP-1 inhibitory activity than compounds $7 \mathbf{a}$ and $\mathbf{7 b}$. These results suggest that the dimeric cinnamate or salicylate structure as linked by disulfide bond may chelate zinc ion and may be necessary for MMP inhibition. ${ }^{10,11)}$ It should be noted that our compounds are different from the peptide-mimicking GM-1489, which displayed greater efficacy as MMP inhibitor. The difference in chemical structure suggests that our compounds and GM-1489 may
A.

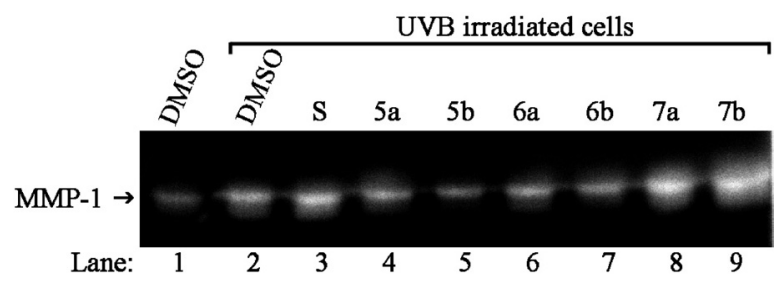

B.

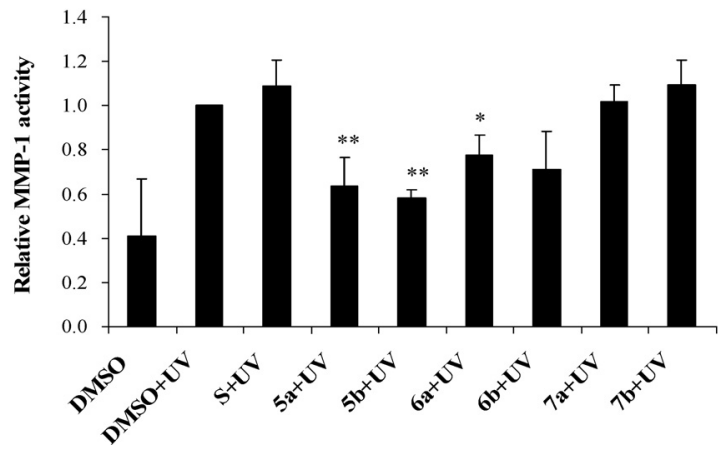

Fig. 4. Inhibitory Effect of Compounds 5a-7b on MMP Zymography

(A) Casein-zymography. MMP-1 activity in conditioned medium from UVB $\left(40 \mathrm{~mJ} / \mathrm{cm}^{2}\right)$-irradiated HDF cells was analyzed in the absence or presence of $1 \mu \mathrm{M}$ test compounds. (B) Relative inhibitory potency of compounds $\mathbf{5 a - 7 b}$ on MMP-1 activity. The gel image in panel A was quantitated and the results are expressed as relative intensity of the clear band in the gel (arrow indicated). Each bar represents the mean \pm S.D. of three independent experiments. $* p<0.05 ; * * p<0.01$ compared with control (lane 2) group.

have different action mechanism in inhibition of MMP activity.

Casein-Zymography In casein-zymography, ${ }^{21)}$ the inhibitory activity of our synthetic compounds on MMP activity was assessed using conditioned medium from UVB-irradiated HDF cells that were treated with $1 \mu \mathrm{M}$ of our synthetic compounds. The MMP activity in these conditioned medium was assessed by casein-zymography. As shown in Fig. 4, the efficacy of these compounds on inhibition of the caseinolytic activity was in the following order: $5 b>5 a \approx 6 b \approx 6 a>7 a \approx$ $7 \mathbf{b}$.

In this study, two methods were employed to evaluate the MMP-1 inhibitory activity of these compounds. The collagen degradation assay showed in vitro inhibition of MMP-1 enzyme activity. In contrast, the casein-zymography did not show simple MMP-1 inhibition. In fact, the effect as seen casein-zymography method includes the inhibition of MMP1 gene transcription or translation as well as the inhibition of MMP-1 activity itself. Since the results obtained from these two methods appear to be consistent, MMP-1 inhibition by these compounds in zymography may be mainly due to direct inhibition of MMP-1 enzyme activity. However, it is also possible that the greater activity of compounds $\mathbf{5 a}$ and $\mathbf{5 b}$ in zymography assay was resulted from their UV-filtering effect. As compounds $\mathbf{5} \mathbf{a}$ and $\mathbf{5 b}$ possess more extensive conjugating double system of the cinnamate moiety and may better protect the cells against UV-irradiation.

In summary, we have synthesized a series of sulfur-containing cinnamate and salicylate derivatives in this study. Our results demonstrated that these sulfur-containing compounds 
exhibit evident antioxidative activity that enables them to be potential antioxidative. Among these compounds, $\mathbf{5 a}, \mathbf{5 b}$, and 6a conferred marked MMP-1 inhibitory activity in collagenolytic assay and caseinolytic zymographic analysis. We found that the free thiol group is important for marked free radical scavenging activity and the disulfide linkage may be important for MMP-1 inhibition. These observations also suggest that the free radical scavenging and MMP inhibitory activities of these compounds are conveyed by different mechanisms. Despite that there is no direct correlation between free radical scavenging and MMP-1 inhibitory activities, our studies reveal structure features for the further development of effective compounds as sunscreening and MMP-1 inhibitors that may have potential applications. Further experiments evaluating the UV-protective effects and action mechanism of these compounds in normal cells or mice are currently in progress.

\section{Experimental}

General Melting points (mp) were taken on a BUCHI 530 apparatus and are uncorrected. Merck Art No. 105554 plates precoated with Silica gel 60 containing fluorescent indicator were used for thin-layer chromatography, and Silica gel 60 (Merck Art No 109385, 230 - 400 mesh) was employed for column chromatography. Evaporations were carried out at $<50^{\circ} \mathrm{C}$ using a rotary evaporator at reduced pressure (water aspirator). ${ }^{1} \mathrm{H}$ - and ${ }^{13} \mathrm{C}-\mathrm{NMR}$ spectra were obtained with a Varian 300 NMR spectrometer at 300 and $75 \mathrm{MHz}$, respectively. Where necessary, deuterium exchange experiments were used to obtained proton shift assignments. Mass spectra were recorded on a JEOL J.M.S-300 spectrophotometer. Analytical samples were dried under reduced pressure at $78^{\circ} \mathrm{C}$ in the presence of $\mathrm{P}_{2} \mathrm{O}_{5}$ for at least $12 \mathrm{~h}$ unless otherwise specified. Elemental analyses were obtained using a PerkinElmer 2400 Elemental Analyzer.

2-Mercaptobenzyl Alcohol (1) The suspension of $\mathrm{LiAlH}_{4}(9.8 \mathrm{~g}$, $260 \mathrm{mmol})$ in dry tetrahydrofuran (THF) $(80 \mathrm{ml})$ was added dropwise to a solution of 2-mercaptobenzoic acid $(16.0 \mathrm{~g}, 104 \mathrm{mmol})$ in dry THF $(120 \mathrm{ml})$. After stirring at room temperature for $4 \mathrm{~h}, 10 \% \mathrm{H}_{2} \mathrm{SO}_{4}(100 \mathrm{ml})$ and ethyl acetate $(120 \mathrm{ml})$ were added carefully and the reaction mixture was filtered. The residue was washed with ethyl acetate $(3 \times 40 \mathrm{ml})$. The filtrate and washings were combined, dried with magnesium sulfate, and concentrated under reduced pressure to give an oily product which became solid after cooling. Crystallization with a mixture of $n$-hexane and ethyl acetate, gave pure compound $(8.0 \mathrm{~g}, 55 \%)$, mp: $31-32^{\circ} \mathrm{C}$, (lit. $\left.{ }^{13)} 31-32^{\circ} \mathrm{C}\right)$.

2,2'-Dithiodibenzaldehyde (2) A mixture of pyridine chlorochromate $(36.0 \mathrm{~g}, 167.0 \mathrm{mmol})$ in dry dichloromethane $(150 \mathrm{ml})$ under nitrogen atmosphere was added dropwise to the mixture of $1(11.7 \mathrm{~g}, 84 \mathrm{mmol})$ in dry dichloromethane $(150 \mathrm{ml})$. After stirring at room temperature for $4 \mathrm{~h}$, the reaction mixture was filtered. The residue was washed with dichloromethane $(3 \times 40 \mathrm{ml})$ and ether $(40 \mathrm{ml})$. The filtrate and washings were combined, and then concentrated to give the solid product. Crystallization with ethanol gave pure compound $(6.1 \mathrm{~g}, 52 \%)$, mp: $145-148^{\circ} \mathrm{C}$, (lit. ${ }^{13)} 145-148^{\circ} \mathrm{C}$ ).

Bromo-acetic 2-Ethyl-hexyl Ester (3) In a two-necked round bottom flask equipped with a Dean-Stark apparatus 2-ethyl-hexanol $(9.4 \mathrm{~g}$, $72 \mathrm{mmol})$ and $\mathrm{p}-\mathrm{TsOH}(8.6 \mathrm{~g}, 45 \mathrm{mmol})$ were added to a solution of bromoacetic acid $(8.3 \mathrm{~g}, 60 \mathrm{mmol})$ in toluene $(200 \mathrm{ml})$. After stirring under reflux for $18 \mathrm{~h}$, toluene was removed under vacuum. The residue dissolved in ethyl acetate $(3 \times 40 \mathrm{ml})$ was washed with saturated aqueous $\mathrm{NaHCO}_{3}$ $(30 \mathrm{ml})$, water $(2 \times 30 \mathrm{ml})$, brine $(2 \times 30 \mathrm{ml})$, dried over $\mathrm{MgSO}_{4}$ and concentrated. Purification by column chromatography on silica (nhexane $/ \mathrm{EtOAc}=9 / 1)$ afforded a colorless oil $13.5 \mathrm{~g}, 89 \%$. Rf $0.35(n-$ hexane/EtOAc $=9 / 1) .{ }^{1} \mathrm{H}-\mathrm{NMR}\left(\mathrm{CDCl}_{3}\right) \delta: 4.03\left(2 \mathrm{H}, \mathrm{d}, J=6.0 \mathrm{~Hz}, \mathrm{OCH}_{2}\right)$, $3.78\left(2 \mathrm{H}, \mathrm{s}, \mathrm{CH}_{2}\right), 1.54-1.52(1 \mathrm{H}, \mathrm{m}, \mathrm{CH}), 1.12-1.26\left(8 \mathrm{H}, \mathrm{m}, \mathrm{CH}_{2}\right)$, $0.88-0.85\left(6 \mathrm{H}, \mathrm{m}, \mathrm{CH}_{3}\right)$.

2-Ethylhexyloxycarbonyltriphenylphosphonium Bromide (4) Triphenylphosphine $(0.84 \mathrm{~g}, 3.2 \mathrm{mmol})$ was dissolved in benzene or toluene $(15 \mathrm{ml}) .3(3.8 \mathrm{ml}, 26 \mathrm{mmol})$ was added to the solution. The mixture was swirled well and almost immediately became cloudy. White precipitate formed within $10 \mathrm{~min}$. The mixture was allowed to stand at room temperature for at least $4 \mathrm{~h}$ before collecting the precipitate. The solid was filtered, washed with toluene, then with hexanes, and allowed to dry over vacuum. The product was not purified further but used directly for Wittig reactions.
The product was stored in the refrigerator to give product $0.34 \mathrm{~g}$. Yield: $30 \%$. mp: $136-140{ }^{\circ} \mathrm{C} . R f 0.5$ ( $n$-hexane). ${ }^{1} \mathrm{H}-\mathrm{NMR}\left(\mathrm{CDCl}_{3}\right) \delta: 7.91-7.83$ (6H, m, ArH), 7.78-7.73 (3H, m, ArH), 7.67-7.63 (6H, m, ArH), 5.44 $\left(2 \mathrm{H}, \mathrm{d}, J=13.8 \mathrm{~Hz}, \mathrm{CH}_{2}\right), 3.85\left(2 \mathrm{H}, \mathrm{d}, J=7.2 \mathrm{~Hz}, \mathrm{OCH}_{2}\right), 1.36-1.32(1 \mathrm{H}$, $\mathrm{m}, \mathrm{CH}), 1.15-1.06\left(8 \mathrm{H}, \mathrm{m}, \mathrm{CH}_{2}\right), 0.82\left(3 \mathrm{H}, \mathrm{t}, J=6.9 \mathrm{~Hz}, \mathrm{CH}_{3}\right), 0.72(3 \mathrm{H}, \mathrm{t}$, $J=7.5 \mathrm{~Hz}, \mathrm{CH}_{3}$ ).

General Procedure to Obtain Compounds 5a and 5b Dry nitrogen gas was passed through the apparatus for $15 \mathrm{~min}$. Into the flask was placed a suspension of 4 or triethyl phophonoacetate (TPA) $(20 \mathrm{mmol})$ in THF $(50 \mathrm{ml})$, and the $2(10 \mathrm{mmol})$ was added. The reaction mixture was maintained under a positive pressure from dry nitrogen and was stirred, while being cooled in an ice-water bath, for $20 \mathrm{~min} .60 \% \mathrm{NaH}(15 \mathrm{mmol})$ was added in a single portion. It was stirred for an additional $20 \mathrm{~min}$ in the icewater bath. The bath was then removed, and the reaction mixture was allowed to return to room temperature. The reaction mixture was then allowed to stand at room temperature for $6 \mathrm{~h}$. The reaction mixture was gravity filtered while it was still warm. The precipitate was washed with additional dry THF. The filtrate was collected and the solvent was removed by vacuum evaporation to oil. The resultant oil was purified by chromatography on silica gel $(n$-hexane/EtOAc $=2 / 1)$ to give product.

2,2'-Dithiobiscinnamic Acid Bis(2-ethylhexyl) Ester (5a): Yield: 45\%. $R f$ $0.4(n$-hexane/EtOAc $=2 / 1) .{ }^{1} \mathrm{H}-\mathrm{NMR}\left(\mathrm{CDCl}_{3}\right) \delta: 8.18(1 \mathrm{H}, \mathrm{d}, J=15.9 \mathrm{~Hz}$, $\mathrm{CH}), 7.55-7.32(4 \mathrm{H}, \mathrm{m}, \mathrm{Ar}-\mathrm{H}), 7.30-7.25(4 \mathrm{H}, \mathrm{m}, \mathrm{Ar}-\mathrm{H}), 6.36(1 \mathrm{H}, \mathrm{d}$, $J=15.9 \mathrm{~Hz}, \mathrm{CH}), 4.12\left(2 \mathrm{H}, \mathrm{d}, J=5.7 \mathrm{~Hz}, \mathrm{OCH}_{2}\right.$, each), $1.57-1.43(1 \mathrm{H}, \mathrm{m}$, $\mathrm{CH}$, each), $1.42-1.24\left(8 \mathrm{H}, \mathrm{m}, \mathrm{CH}_{2}\right.$, each), $0.94-0.87$ (6H, $\mathrm{m}, \mathrm{CH}_{3}$, each). ${ }^{13} \mathrm{C}-\mathrm{NMR}\left(\mathrm{CDCl}_{3}\right) \delta: 166.23,141.28,136.15,134.71,132.76,129.67$, $127.64,126.76,120.19,66.54,41.36,38.346,29.94,28.34,22.29,13.28$, 10.34. IR (KBr) cm ${ }^{-1}: 1672$. UV $\lambda_{\max }\left(\mathrm{CH}_{2} \mathrm{Cl}_{2}\right) \mathrm{nm}(\log \varepsilon): 359$ (1.0). FABMS $m / z: 583(\mathrm{M}+\mathrm{H})^{+}$. Anal. Calcd for $\mathrm{C}_{34} \mathrm{H}_{46} \mathrm{O}_{4} \mathrm{~S}_{2}: \mathrm{C}, 70.06 ; \mathrm{H}, 7.95$. Found: C, 70.39; H, 7.99.

2,2'-Dithiobiscinnamic Acid Diethyl Ester (5b): Yield: 73\%. Rf $0.2(n-$ hexane/EtOAc $=2 / 1) .{ }^{1} \mathrm{H}-\mathrm{NMR}\left(\mathrm{CDCl}_{3}\right) \delta: 8.09(1 \mathrm{H}, \mathrm{d}, J=15.9 \mathrm{~Hz}, \mathrm{CH})$, $7.56-7.51(4 \mathrm{H}, \mathrm{m}, \mathrm{Ar}-\mathrm{H}), 7.26-7.29(4 \mathrm{H}, \mathrm{m}, \mathrm{Ar}-\mathrm{H}), 6.29(1 \mathrm{H}, \mathrm{d}$, $J=15.9 \mathrm{~Hz}, \mathrm{CH}), 4.26\left(2 \mathrm{H}, \mathrm{q}, J=7.2 \mathrm{~Hz}, \mathrm{CH}_{2}\right.$, each), $1.33(3 \mathrm{H}, \mathrm{t}, J=7.2 \mathrm{~Hz}$, $\mathrm{CH}_{3}$, each). ${ }^{13} \mathrm{C}-\mathrm{NMR}\left(\mathrm{CDCl}_{3}\right) \delta: 165.90,140.53,136.27,135.61,131.91$, $129.95,128.30,126.69,120.39,59.92,13.64$. IR $(\mathrm{KBr}) \mathrm{cm}^{-1}: 1672$. UV $\lambda_{\max }\left(\mathrm{CH}_{2} \mathrm{Cl}_{2}\right) \mathrm{nm}(\log \varepsilon): 359$ (1.0). EI-MS m/z: $414\left(\mathrm{M}^{+}\right)$. Anal. Calcd for $\mathrm{C}_{22} \mathrm{H}_{22} \mathrm{O}_{4} \mathrm{~S}_{2}: \mathrm{C}, 63.74 ; \mathrm{H}, 5.35$. Found: $\mathrm{C}, 63.80 ; \mathrm{H}, 5.40$.

General Procedure to Obtain Compounds 6a and 6b A mixture of 2mercaptobenzoic acid $(60 \mathrm{mmol})$, 2-ethyl-hexanol or ethanol $(120 \mathrm{ml})$ and concentrated sulfuric acid $(3 \mathrm{ml})$ was heated under reflux for $24 \mathrm{~h}$. The solvent of reaction mixture was removed and the residue was partitioned between EtOAc and saturated $\mathrm{NaHCO}_{3}$. The organic layer was collected, washed with brine and concentrated. The residue was purified by chromatography silica gel $(n$-hexane/EtOAc $=9 / 1)$ to give oil product.

2,2'-Dithiobisbenzoic Acid Bis(2-ethylhexyl) Ester (6a): Yield: 52\%. Rf $0.7(n$-hexane/EtOAc $=9 / 1) .{ }^{1} \mathrm{H}-\mathrm{NMR}\left(\mathrm{CDCl}_{3}\right) \delta: 8.06(2 \mathrm{H}, \mathrm{d}, J=7.8 \mathrm{~Hz}$, $\mathrm{ArH}), 7.77(4 \mathrm{H}, \mathrm{d}, J=8.1 \mathrm{~Hz}, \mathrm{ArH}), 7.41(4 \mathrm{H}, \mathrm{t}, J=7.2 \mathrm{~Hz}, \mathrm{ArH}), 7.24(4 \mathrm{H}$, $\mathrm{t}, J=7.2 \mathrm{~Hz}, \mathrm{ArH}), 4.31\left(4 \mathrm{H}, \mathrm{q}, J=2.1 \mathrm{~Hz}, \mathrm{CH}_{2}\right), 1.54-1.52(1 \mathrm{H}, \mathrm{m}, \mathrm{CH}$, each), $1.49-1.33\left(8 \mathrm{H}, \mathrm{m}, \mathrm{CH}_{2}\right.$, each), $0.94-0.91\left(3 \mathrm{H}, \mathrm{m}, \mathrm{CH}_{3}\right.$, each). ${ }^{13} \mathrm{C}-$ NMR $\left(\mathrm{CDCl}_{3}\right) \delta: 166.19,139.95,132.39,130.84,127.39,125.44,124.93$, 67.36, 38.35, 29.99, 28.36, 23.41, 22.3, 13.31, 10.39. IR (KBr) cm ${ }^{-1}: 1674$. UV $\lambda_{\max }\left(\mathrm{CH}_{2} \mathrm{Cl}_{2}\right) \mathrm{nm}(\log \varepsilon): 358(1.0)$. EI-MS $m / z: 530\left(\mathrm{M}^{+}\right)$. Anal. Calcd for $\mathrm{C}_{30} \mathrm{H}_{42} \mathrm{O}_{4} \mathrm{~S}_{2}: \mathrm{C}, 67.89 ; \mathrm{H}, 7.98$. Found: $\mathrm{C}, 68.05 ; \mathrm{H}, 7.99$.

2,2'-Dithiobisbenzoic Acid Diethyl Ester (6b): Yield: 67\%. Rf $0.7(n-$ hexane/EtOAc $=7 / 1) .{ }^{1} \mathrm{H}-\mathrm{NMR}\left(\mathrm{CDCl}_{3}\right) \delta: 8.07(2 \mathrm{H}, \mathrm{d}, J=1.5 \mathrm{~Hz}, \mathrm{ArH})$, $7.74(4 \mathrm{H}, \mathrm{d}, J=0.9 \mathrm{~Hz}, \mathrm{ArH}), 7.43-7.22(4 \mathrm{H}, \mathrm{m}, \operatorname{ArH}), 4.44(2 \mathrm{H}, \mathrm{q}$, $J=7.5 \mathrm{~Hz}, \mathrm{CH}_{2}$, each), $1.44\left(3 \mathrm{H}, \mathrm{t}, J=1.2 \mathrm{~Hz}, \mathrm{CH}_{3}\right.$, each). ${ }^{13} \mathrm{C}-\mathrm{NMR}$ $\left(\mathrm{CDCl}_{3}\right) \delta: 165.98,139.90,132.32,130.82,127.50,125.51,124.89,60.83$, 13.61. IR $(\mathrm{KBr}) \mathrm{cm}^{-1}: 1672$. UV $\lambda_{\max }\left(\mathrm{CH}_{2} \mathrm{Cl}_{2}\right) \mathrm{nm}(\log \varepsilon): 357$ (1.0). EIMS $m / z: 362\left(\mathrm{M}^{+}\right)$. Anal. Calcd for $\mathrm{C}_{18} \mathrm{H}_{18} \mathrm{O}_{4} \mathrm{~S}_{2}: \mathrm{C}, 59.65 ; \mathrm{H}, 5.01$. Found: C, 59.68; H, 5.1.

General Procedure to Obtain Compounds 7a and $7 \mathbf{b}$ Dry nitrogen gas was passed through the apparatus for $15 \mathrm{~min}$. The flask was charged with 6a or $6 \mathbf{b}(4.1 \mathrm{mmol})$ and freshly distilled THF $(60 \mathrm{ml})$. To this well-stirred solution, maintained at room temperature was added a $1.25 \mathrm{~m}$ solution of lithium tri-tert-butoxyaluminohydride (LTBA) $(8.2 \mathrm{mmol})$ in THF by a syringe needle over a 15 -min period. The resulting clear mixture was stirred for an additional period of $4 \mathrm{~h}$. Water $(1 \mathrm{ml})$ was added dropwise to destroy the excess hydride. The mixture was acidified by the addition of $6.0 \mathrm{~N}$ hydrochloric acid to attain a $\mathrm{pH}$ of $<3$. The organic phase was separated, and the aqueous phase was extracted with ethyl acetate $(3 \times 30 \mathrm{ml})$. The combined extracts were washed with saturated brine $(30 \mathrm{ml})$ and dried with $\mathrm{MgSO}_{4}$. Removal of ethyl acetate solvents on a rotary evaporator followed 
by vacuum drying yielded $91 \%$ and $94 \%$ of $7 \mathbf{a}$ and $\mathbf{7 b}$, respectively.

2-Ethylhexyl 2-Mercaptobenzoic Acid (7a): Yield: 91\%. Rf 0.4 (nhexane/EtOAc $=7 / 1) .84-86{ }^{\circ} \mathrm{C}\left(\mathrm{CH}_{2} \mathrm{Cl}_{2}\right) .{ }^{1} \mathrm{H}-\mathrm{NMR}\left(\mathrm{CDCl}_{3}\right) \delta: 8.03(1 \mathrm{H}$ q, $J=1.5 \mathrm{~Hz}, \operatorname{ArH}), 7.33(1 \mathrm{H}, \mathrm{q}, J=1.5 \mathrm{~Hz}, \operatorname{ArH}), 7.29(1 \mathrm{H}, \mathrm{d}, J=0.9 \mathrm{~Hz}$, $\mathrm{ArH}), 7.17-7.10(1 \mathrm{H}, \mathrm{m}, \mathrm{ArH}), 2.79\left(2 \mathrm{H}, \mathrm{d}, J=6.3 \mathrm{~Hz}, \mathrm{OCH}_{2}\right), 1.56-1.54$ $(1 \mathrm{H}, \mathrm{m}, \mathrm{CH}), 1.52-1.29\left(8 \mathrm{H}, \mathrm{m}, \mathrm{CH}_{2}\right), 0.93-0.89\left(6 \mathrm{H}, \mathrm{m}, \mathrm{CH}_{3}\right) .{ }^{13} \mathrm{C}-\mathrm{NMR}$ $\left(\mathrm{CDCl}_{3}\right) \delta: 170.12,142.53,132.49,132.01,126.41,126.14,123.57,37.82$, $36.55,32.08,28.15,25.2,22.28,13.38,10.03$. IR: $(\mathrm{KBr}) \mathrm{cm}^{-1}: 1676$. UV $\lambda_{\max }\left(\mathrm{CH}_{2} \mathrm{Cl}_{2}\right) \mathrm{nm}(\log \varepsilon): 358(1.0)$. FAB-MS $m / z: 267\left(\mathrm{M}+\mathrm{H}^{+}\right)$. Anal. Calcd for $\mathrm{C}_{15} \mathrm{H}_{22} \mathrm{O}_{2} \mathrm{~S}: \mathrm{C}, 67.63 ; \mathrm{H}, 8.32$. Found: $\mathrm{C}, 67.82 ; \mathrm{H}, 8.42$.

Ethyl 2-Mercaptobenzoic Acid (7b): Yield: 94\%. Rf $0.6 \quad(n-$ hexane $/ \mathrm{EtOAc}=7 / 1) .{ }^{1} \mathrm{H}-\mathrm{NMR}\left(\mathrm{CDCl}_{3}\right) \delta: 7.97(1 \mathrm{H}, \mathrm{d}, J=7.8 \mathrm{~Hz}, \mathrm{ArH})$, $7.25(1 \mathrm{H}, \mathrm{d}, J=1.2 \mathrm{~Hz}, \mathrm{ArH}), 7.10-7.09(2 \mathrm{H}, \mathrm{m}, \mathrm{ArH}), 4.65(1 \mathrm{H}, \mathrm{s}, \mathrm{SH})$ $4.33\left(2 \mathrm{H}, \mathrm{q}, J=7.2 \mathrm{~Hz}, \mathrm{OCH}_{2}\right), 1.36\left(3 \mathrm{H}, \mathrm{t}, J=7.2 \mathrm{~Hz}, \mathrm{CH}_{3}\right) .{ }^{13} \mathrm{C}-\mathrm{NMR}$ $\left(\mathrm{CDCl}_{3}\right) \delta: 166.29,137.55,131.71,131.14,130.37,125.99,124.05,60.57$, 13.56. IR: $(\mathrm{KBr}) \mathrm{cm}^{-1}: 1668$. UV $\lambda_{\text {max }}\left(\mathrm{CH}_{2} \mathrm{Cl}_{2}\right) \mathrm{nm}(\log \varepsilon): 355$ (1.0). EIMS $m / z: 182\left(\mathrm{M}^{+}\right)$. Anal. Calcd for $\mathrm{C}_{9} \mathrm{H}_{10} \mathrm{O}_{2} \mathrm{~S}: \mathrm{C}, 59.32 ; \mathrm{H}, 5.53$. Found: $\mathrm{C}$, $59.41 ; \mathrm{H}, 5.62$

Cell Culture Primary human dermal fibroblast (HDF) cells were purchased from Cascade Biologics (Portland, OR, U.S.A.). HDF cells were grown at $37{ }^{\circ} \mathrm{C}$ in a humidified incubator under $5 \% \mathrm{CO}_{2} / 95 \%$ air in Medium 106 and supplemented with LSGS Kit (Cascade Biologics) and 10\% fetal bovine serum. Culture medium was replaced every other day. Cells between passages 2 and 10 were used for studies.

Cell Viability Assay Cell viability was assessed by CCK- 8 solution (Dojindo Molecular Technologies, Inc., Kumamoto, Japan) by combining WST [2-(2-methoxy-4-nitrophenyl)-3-(4-nitrophenyl)-5-(2,4-disulfophenyl)$2 H$-tetrazolium] and 1-methoxy PMS [1-methoxy-phenazine methosulfate] as described by the manufacturer. Briefly, cells were seeded in 96-well plates at the density of $1 \times 10^{4}$ cells/well $24 \mathrm{~h}$ prior to treatment. Compounds were added to the medium as a concentration stock and the control cells were fed with medium containing the same amount of drug-free vehicle. After incubation for $48 \mathrm{~h}, 10 \mu \mathrm{l}$ of CCK- 8 was added and cells were further incubated for $3 \mathrm{~h}$. Relative cell viability was obtained by measuring absorbance at $450 \mathrm{~nm}$ using an ELISA microplate reader (Spectra Max 190, Molecular Devices, Sunnyvale, CA, U.S.A.)

ABTS Radical Scavenging Assay In vitro antioxidant activity of test compounds was evaluated using an improved $\mathrm{ABTS}^{\cdot+}$ scavenging assay described by Re et al. ${ }^{17)}$ Briefly, the purple ABTS ${ }^{+}$solution $(7.5 \mathrm{~mm})$ was prepared by mixing ABTS with potassium persulfate $(2.5 \mathrm{~mm})$ in $\mathrm{H}_{2} \mathrm{O}$ overnight in the dark at room temperature. The $\mathrm{ABTS}^{+}$solution was diluted with ethanol or PBS ( $\mathrm{pH} 7.4$ ) to an $\mathrm{A}_{734}$ of $0.70 \pm 0.02$ for assay. Six minutes after the $5 \mu \mathrm{l}$ of studied compounds was added to $30 \mu \mathrm{l}$ of ABTS ${ }^{*+}$ dilution, the amount of $\mathrm{ABTS}^{-+}$remaining was determined at $734 \mathrm{~nm}$, and the radical scavenging activity was obtained from the following equation:

$$
\text { radical scavenging activity }(\%)=\left[\left(A_{\text {control }}-A_{\text {sample }}\right) / A_{\text {control }}\right] \times 100
$$

Collagen Degradation Assay Rat tail collagen (BD Biosciences, San Jose, CA, U.S.A.) was diluted to $238 \mu \mathrm{g} / \mu \mathrm{l}$ in Tris-glucose $(0.5 \mathrm{M}$ Glucose and 0.33 M Tris). Purified MMP-1 (Calbiochem, San Diego, CA, U.S.A.) was diluted to $6 \times 10^{-4} \mu \mathrm{g} / \mu 1$ with Tris-glucose. Degradation of the native collagen was carried out by mixing $19 \mu \mathrm{l}$ of MMP-1 solution, $9 \mu \mathrm{l}$ of collagen solution and $2 \mu \mathrm{l}$ of $1 \mathrm{~mm}$ synthetic compounds and incubated for $18 \mathrm{~h}$ at $37^{\circ} \mathrm{C}$. Intact collagen exposed to buffer alone served as control. Collagen fragments released were resolved by SDS-PAGE $(8.5 \% \mathrm{gel})$ and staining with coomassie brilliant blue R-250. The relative intensity of the protein bands were measured by Image analyzing system (Alpha Innotech, St. San Leandro, CA, U.S.A.).

UVB Irradiation and Zymography To characterize the effect of compounds $\mathbf{5 a}-7 \mathbf{b}$ on the expression level of MMP-1 activity in human cells, HDF cells were first treated with or without final concentrations of $1 \mu \mathrm{M}$ $\mathbf{5 a}-7 \mathbf{b}$ for $24 \mathrm{~h}$. For UV irradiation, the cells were irradiated with $40 \mathrm{~mJ} / \mathrm{cm}^{2}$ of UV-B $(312 \mathrm{~nm})$ for HDF cells, using the UV light irradiator (UVItec unlimited, Cambridge, England). The cells were then washed and incubated with serum free medium for $24 \mathrm{~h}$ before harvested for analysis. The enzymic activity of MMP-1 in conditioned medium of UVB-irradiated HDF-1 cells was assayed by casein-zymography according to the method of Bachmeier $e t a l .{ }^{21)}$ The conditioned media were separated by electrophoresis on an $8.5 \%$ SDS-polyacrylamide gel containing $0.33 \mathrm{mg} / \mathrm{ml}$ casein. The electrophoresed gel was washed twice with washing buffer containing $2.5 \%$ triton X-100, followed by a brief rinsing in washing buffer without triton X100. The gel was then immersed for $18 \mathrm{~h}$ in incubation buffer of $50 \mathrm{~mm}$ Tris-HCl, pH 7.5, $150 \mathrm{~mm} \mathrm{NaCl}, 10 \mathrm{~mm} \mathrm{CaCl}_{2}, 0.2 \%$ Brij 35 at $37^{\circ} \mathrm{C}$. After incubation, the gel was stained with $0.25 \%$ Coomassie blue R-250. The presence of MMP-1 was identified with a clear band of casein digestion.

Acknowledgments The authors would like to thank the National Defense University and National Defense Medical Center for supporting this research. This study was supported by grants from the National Science Council (NSC 94-2320-B-016-041 and DOD-95-15 to T-C Chang and NSC 95-2314-B-157-001 to L-Y Hsu), Taiwan, ROC.

\section{References}

1) Kim J. H., Cho Y. H., Lee K. E., Lee J. J., Lee B. C., Pyo H. B., Song K. S., Park H. D., Yun Y. P., Arch. Pharm. Res., 27, 177-183 (2004).

2) Bergeron R. J., Huang G., Weimar W. R., Smith R. E., Wiegand J., McManis J. S., J. Med. Chem., 46, 16-24 (2003).

3) Brennan M., Bhtti H., Nerusu K. C., Bhagavathula N., Kang S., Fisher G. J., Varani J., Voorhees J. J., Photochem. Photobiol., 78, 43-48 (2003).

4) Ropke C. D., Silva V. V., Kera C. Z., Miranda D. V., Almeida R. L., Sawada T. C. H., Barros S. B. M., Photochem. Photobiol., 82, 439442 (2006)

5) Lee Y. S., Jin D. Q., Beak S. M., Lee E. S., Kim J. A., Eur. J. Pharmacol., 476, 173-178 (2003).

6) Fligiel S. E. G., Varani J., Datta S. C., Kang S., Fisher G., Voorhees J. J., J. Invest. Dermatol., 120, 842-848 (2003).

7) Varani J., Warner R. L., Gharaee-Kermani M., Phan S. H., Kang S., Chung J., Wang Z. Q., Datta S. C., Fsher G. J., Voorhees J. J., J. Invest. Dermatol., 120, 480 - 486 (2000).

8) Nagase K., Biol. Chem., 378, 151-160 (1997)

9) Lowe N. J., Shaath N. A., Madhu A. P., "Sunscreens: Development, Evaluation, and Regulatory Aspects," 2nd ed., Marcel Dekker, Inc., New York, 1997, pp. 3-58

10) Loo J. A., Holler T. P., Sanchez J., Gogliotti R., Maloney L., Reily M. D., J. Med. Chem., 39, 4313-4320 (1996).

11) Domagala J. M., Gogliotti R., Sanchez J. P., Stier M. A., Musa K., Song Y., Loo J., Reily M., Tummino P., Harvey P., Hupe D., Sharmeen L., Mack D., Scholten J., Saunders J., Mcquade T., Drug Design and Discovery, 15, 49—61 (1997).

12) Fujisawa T., Odake S., Ogawa Y., Yasuda J., Morita Y., Morikawa T., Chem. Pharm. Bull., 50, 239-252 (2002).

13) Jiang J. J., Chang T. C., Hsu W. L., Hwang J. M., Hsu L. Y., Chem. Pharm. Bull., 51, 1307-1310 (2003).

14) Etzenhouser B., Hansch C., Kapur S., Selassie C. D., Bioorg. Med. Chem., 9, 199-209 (2001).

15) Wang Y. C., Lin C. H., Chen C. M., Liou J. P., Tetrahedron Lett., 46, 8103-8104 (2005).

16) Ferle-Vidovic A., Jukic I., Skare D., Suman L., Vukovic L., Cancer Biother. Radiopharm., 18, 781-790 (2003).

17) Re R., Pellegrini N., Proteggente A., Pannala A., Yang M., Rice-Evans C., Free Radical Biol. Med., 26, 1231-1237 (1999).

18) Hung C. C., Tsai W. J., Kuo L. M. Y., Kuo Y. H., Bioorg. Med. Chem., 13, 1791-1797 (2005)

19) Miller N., Rice-Evans C., Free Rad. Res., 26, 195-199 (1997).

20) Capizzi R. L., Semin. Oncol., 23, 2-17 (1996).

21) Bachmeier B. E., Nerlich A. G., Boukamp P., Lichtinghagen R., Tschesche H., Fritz H., Fink E., Biol. Chem., 381, 509-516 (2000). 